\title{
Synaptic Cell Adhesion
}

\author{
Markus Missler ${ }^{1}$, Thomas C. Südhof ${ }^{2}$, and Thomas Biederer ${ }^{3}$ \\ ${ }^{1}$ Department of Anatomy and Molecular Neurobiology, Westfälische Wilhelms-University, 48149 Münster, \\ Germany \\ ${ }^{2}$ Department of Molecular and Cellular Physiology and Howard Hughes Medical Institute, Stanford University \\ School of Medicine, Stanford, California 94305 \\ ${ }^{3}$ Department of Molecular Biophysics and Biochemistry, Yale University, New Haven, Connecticut 06520 \\ Correspondence: thomas.biederer@yale.edu
}

Chemical synapses are asymmetric intercellular junctions that mediate synaptic transmission. Synaptic junctions are organized by trans-synaptic cell adhesion molecules bridging the synaptic cleft. Synaptic cell adhesion molecules not only connect pre- and postsynaptic compartments, but also mediate trans-synaptic recognition and signaling processes that are essential for the establishment, specification, and plasticity of synapses. A growing number of synaptic cell adhesion molecules that include neurexins and neuroligins, Igdomain proteins such as SynCAMs, receptor phosphotyrosine kinases and phosphatases, and several leucine-rich repeat proteins have been identified. These synaptic cell adhesion molecules use characteristic extracellular domains to perform complementary roles in organizing synaptic junctions that are only now being revealed. The importance of synaptic cell adhesion molecules for brain function is highlighted by recent findings implicating several such molecules, notably neurexins and neuroligins, in schizophrenia and autism.

\section{SYNAPTIC CELL ADHESION}

Gynapses constitute highly specialized sites of asymmetric cell-cell adhesion and intercellular communication. The very first studies of synapse ultrastructure already described their "triple structure" comprised of pre- and postsynaptic membrane specializations and synaptic cleft material, concluding that "the thickened regions show special adhesive properties (Gray 1959)." Adhesion is an important structural aspect of synapses as evidenced by the fact that pre- and postsynaptic specializations remain tightly attached upon biochemical fractionation (Gray and Whittaker 1962). Indeed, ultrastruc- tural studies have shown that the material crossing the synaptic cleft is periodically organized and composed of highly concentrated proteinaceous material (Lucic et al. 2005; Zuber et al. 2005).

The spatially and temporally coordinated assembly of pre- and postsynaptic membranes is consistent with instructive roles of synaptic cell adhesion in synapse development. The precise overlap of pre- and postsynaptic specializations additionally indicates that interactions across the cleft delineate their mutual boundaries (Schikorski and Stevens 1997). The regular width of the synaptic cleft further shows that adhesive interactions may act as "molecular rulers"

Editors: Morgan Sheng, Bernardo Sabatini, and Thomas Südhof

Additional Perspectives on The Synapse available at www.cshperspectives.org

Copyright (C) 2012 Cold Spring Harbor Laboratory Press; all rights reserved; doi: 10.1101/cshperspect.a005694

Cite this article as Cold Spring Harb Perspect Biol 2012;4:a005694 
M. Missler et al.

to define its span (Palade and Palay 1954; Gray 1959). During synaptogenesis, axonal growth cones and their dendritic targets frequently extend filopodia to form initial contacts (Cooper and Smith 1992). Synaptic membrane specializations assemble at these contacts as ultrastructurally defined by synaptic vesicles, electrondense cleft material, and thickened postsynaptic membranes, and the intercellular distance widens from an initial $13 \mathrm{~nm}$ interstitial space to the final $\sim 20 \mathrm{~nm}$ "cleft" (Rees et al. 1976). Finally, mature synapses are subject to activitydependent structural and functional plasticity mechanisms that remodel them, and that may be regulated by synaptic cell adhesion (Toni et al. 1999; Knott et al. 2002). Moreover, synapses continue to be formed and eliminated throughout the lifetime of an organism. Synapse formation and elimination are most active during the postnatal period of development during which a vertebrate brain acquires maturity, but are continuously operating to support learning and memory processes as well as regenerative processes in disease.

The proteins crossing the synaptic cleft are collectively referred to as synaptic cell adhesion molecules (Akins and Biederer 2006; Piechotta et al. 2006), a somewhat misleading term because these molecules most likely do not only function in cell adhesion, but also in intercellular trans-synaptic signaling. Criteria for a synaptic cell adhesion molecule include their localization to synapses at one or more stages of development, functions in cell-cell interactions, and evidence for altered synapse formation and/or function after the loss-of-function or increased expression of these proteins.

In the present article, we will focus on the contributions of synaptic cell adhesion molecules throughout the lifetime of a synapse. Synapse formation is a complex multistage process. A conceptual division of synapse formation into four stages postulates that initial establishment of synaptic contacts is followed by assembly of the pre- and postsynaptic molecular machinery, functional specification of the incipient synapses, and finally synaptic plasticity (Fig. 1). Contact establishment involves recognition of pre- and postsynaptic neurons at the site of fu- ture synapses. The molecular assembly stage includes recruitment of synaptic vesicles, active zones, and postsynaptic density structures to a developing synaptic contact, resulting in an anatomically identifiable synapse, but does not in itself produce a functional synapse. Functionality of a synapse is achieved with the organization of its molecular components during the functional specification stage, which also confers specific properties to a synapse. Synaptic plasticity is viewed here as an extension of synapse formation that often involves changes akin to the molecular assembly and functional specification of a synapse. All of these stages likely require synaptic cell adhesion molecules and are mediated by sequential protein-protein interactions, and many of these processes are probably activity dependent. The adhesive mechanisms and signaling pathways guiding synapse formation are only now beginning to be recognized.

\section{TOOL BOX OF SYNAPTIC CELL ADHESION: MULTIPLE DOMAINS, BINDING PROPERTIES, AND FUNCTIONS}

Although synaptic cell adhesion molecules comprise a number of proteins that are specialized for distinct functions in the recognition, molecular assembly, and/or specification of chemical synapses, their adhesive and functional specificity is based on a limited number of extracellular domains. These domains are often assembled into repeated units, which may not only increase the number of possible interactions but also allows them to protrude into or cross the synaptic cleft and provide for mechanical stability. Below, we discuss these domains as building blocks of synaptic cell adhesion.

Immunoglobulin- (Ig-) domains. Ig-domains are animal cell adhesion domains that most frequently bind to other Ig-domains, either as homo- and heterophilic complexes. Ig-domains are composed of a $\beta$-sandwich that is often stabilized by a disulfide bond; most cell-adhesion molecules containing Ig-domains also contain fibronectin III (FnIII) domains with a similar $\beta$-sandwich fold.

Cadherin domains. Cadherin domains are characterized by an all- $\beta$ fold, and always occur 

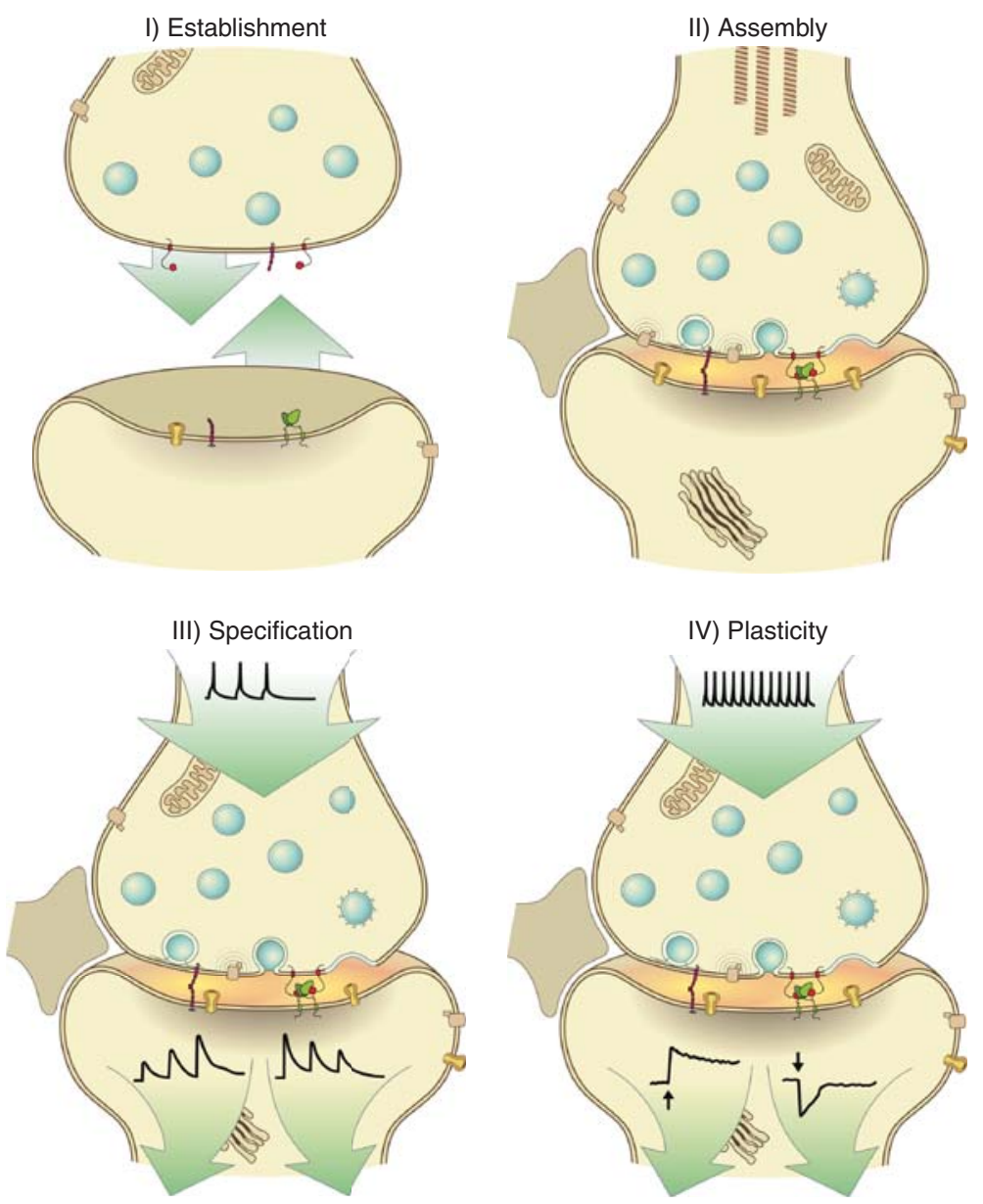

II) Assembly

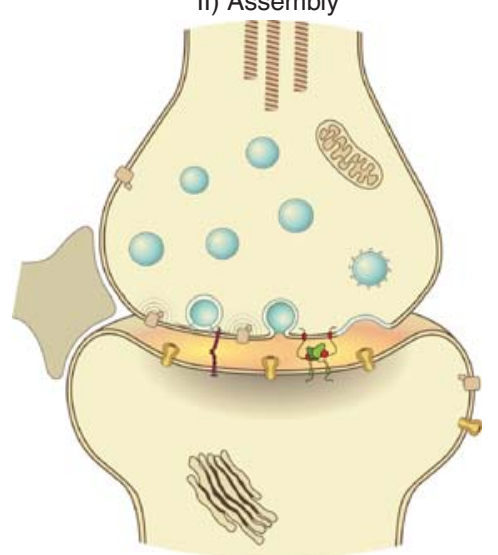

IV) Plasticity

$$
\text { ins }=\begin{gathered}
\text { Heterophilic trans-synaptic } \\
\text { cell adhesion molecules }
\end{gathered} \quad \begin{gathered}
\text { Homophilic trans-synaptic } \\
\text { cell adhesion molecules }
\end{gathered}
$$

Figure 1. Synaptic cell adhesion and synaptic function. Synaptic cell adhesion involves multiple, partially overlapping processes. (I) Initial establishment of axo-dendritic contacts may require heterophilic and homophilic cell adhesion molecules to recognize appropriate pre- and postsynaptic partners. During the molecular assembly (II) and functional specification (III) of synapses, synaptic cell adhesion molecules mediate recognition, physical cell-cell adhesion, and serve as anchor proteins to cluster or recruit receptors and components of the pre- and postsynaptic signaling machinery. Their action eventually leads to synapses with distinct physiological properties as exemplified by distinct responses to the same stimuli. (IV) In adaptive events, for example during memory formation, synaptic cell adhesion molecules also may contribute to structural changes and functional synaptic plasticity such as long-term potentiation or depression.

in multiple copies connected by a linker that binds $2-3 \mathrm{Ca}^{2+}$-ions, which leads to the characteristic curvature of cadherin extracellular domains (Pokutta and Weis 2007). Cadherinmediated interactions are $\mathrm{Ca}^{2+}$-dependent and often homophilic.
Laminin A, neurexin, and sex hormone-binding protein (LNS) domains (a.k.a. laminin Glike LG-domains). LNS domains are composed of a lectin-like $\beta$-sandwich with a conserved $\mathrm{Ca}^{2+}$-binding site at the variable rim (Rudenko et al. 2001; Araç et al. 2007; Reissner et al. 2008). 
M. Missler et al.

In $\alpha$-neurexins and neurexin-related CASPR proteins, several LNS domains are present in a series, often with interspersed rigid EGF-like domains; this arrangement results in a complex L-shaped structure with two hinge-regions in neurexin-1 $\alpha$ (Fig. 2) (Chen et al. 2011; Miller et al. 2011).

Leucin-rich repeats (LRRs). LRRs are not autonomously folded domains but 20-30 residue sequences with a characteristic leucine-rich sequence pattern. Tandem repeats of LRRs, flanked by characteristic amino- and carboxy-terminal sequence motifs, fold into curved solenoid structures stabilized by extensive hydrophobic interactions of their leucine residues.

\section{NEUREXIN AND NEUROLIGIN INTERACTIONS INSTRUCT SYNAPSE SPECIFICATION AND FUNCTION}

Neurexins were identified as a presynaptic receptor for $\alpha$-latrotoxin, a spider toxin that causes massive synaptic vesicle exocytosis (Ushkaryov et al. 1992, 1993, and 1994). Neurexins are presynaptic type I membrane proteins with a large extracellular sequence and a short cytoplasmic tail. Vertebrates contain three neurexin genes (neurexin-1 to -3 , abbreviated here as Nrxl to $\mathrm{Nrx} 3$ ) that produce from independent promoters a longer $\alpha$ - and a shorter $\beta$-neurexin isoform. Extracellularly, $\alpha$-neurexins contain six LNS domains with three interspersed EGF-like domains, whereas $\beta$-neurexins only contain a single LNS-domain that is identical to the sixth LNS-domain of the corresponding $\alpha$-neurexin (Fig. 2) (Ushkaryov et al. 1992, 1993, and 1994). Moreover, neurexins are extensively alternatively spliced at five conserved sites in their extracellular region, creating potentially thousands of isoforms (Ullrich et al. 1995; Tabuchi and Südhof 2002). Intracellularly, the short cytoplasmic tails of neurexins contain PDZ-domain binding sequences that bind to CASK (a hybrid kinase/MAGUK protein that was identified as a neurexin-interacting protein; Hata et al. 1996) and to protein 4.1 in a trimeric complex (Biederer and Südhof 2001). Neurexins are evolutionarily conserved and pan-neuronally expressed (Tabuchi and Südhof 2002; Haklai-Topper et al.
2011). In vertebrates, different neurexin isoforms and splice variants are differentially expressed, consistent with the notion that they mediate a recognition code (Ullrich et al. 1995).

Neuroligins are postsynaptic type I membrane proteins that were identified as neurexin ligands (Ichtchenko et al. 1995, 1996). Neuroligins are expressed from four genes in vertebrates (neuroligin-1 to -4 , abbreviated here as NL1 to NL4). Primates contain nonrecombining copies of neuroligin-4 on the X- and Y-chromosomes, with the Y-chromosomal copy often referred to as neuroligin-5. $\alpha$ - and $\beta$-neurexins both bind to all neuroligins to form cell adhesion complexes (Boucard et al. 2005). In contrast to neurexins, neuroligins are specifically localized to particular synapses. NL1 is only present at excitatory synapses (Song et al. 1999), NL2 and NL4 at inhibitory synapses (Varoqueaux et al. 2004; Hoon et al. 2011), whereas NL3 is present at both excitatory and inhibitory synapses (Budreck and Scheiffele 2007). The extracellular sequence of neuroligins is largely composed of a single esterase-like domain that forms a constitutive dimer, whereas their cytoplasmic tails contain a PDZ-domain binding sequence that recruits PSD-95 and other PDZ-domain proteins (Irie et al. 1997), and tyrosine-based motif that binds to gephyrin (Poulopoulos et al. 2009). It is currently unclear how neuroligins are specifically recruited to excitatory or inhibitory synapses because all neuroligins similarly interact in vitro with excitatory- and inhibitoryspecific cytoplasmic proteins (PSD-95 and gephyrin, respectively).

Binding of neurexins to neuroligins is mediated by the sixth LNS domain of $\alpha$-neurexin and the single LNS domain of $\beta$-neurexin, and likely forms a trans-synaptic complex. Although $\alpha$ - and $\beta$-neurexins bind to neuroligins via the same LNS domain, their binding properties are different (Boucard et al. 2005; Reissner et al. 2008). Moreover, different neurexin and neuroligin isoforms show distinct binding affinities. Most importantly, however, binding of neurexins and neuroligins is tightly regulated by alternative splicing, especially at the splice site 4 in the shared LNS-domain of $\alpha$ - and $\beta$-neurexins (Ichtchenko et al. 1995; Boucard et al. 2005). 

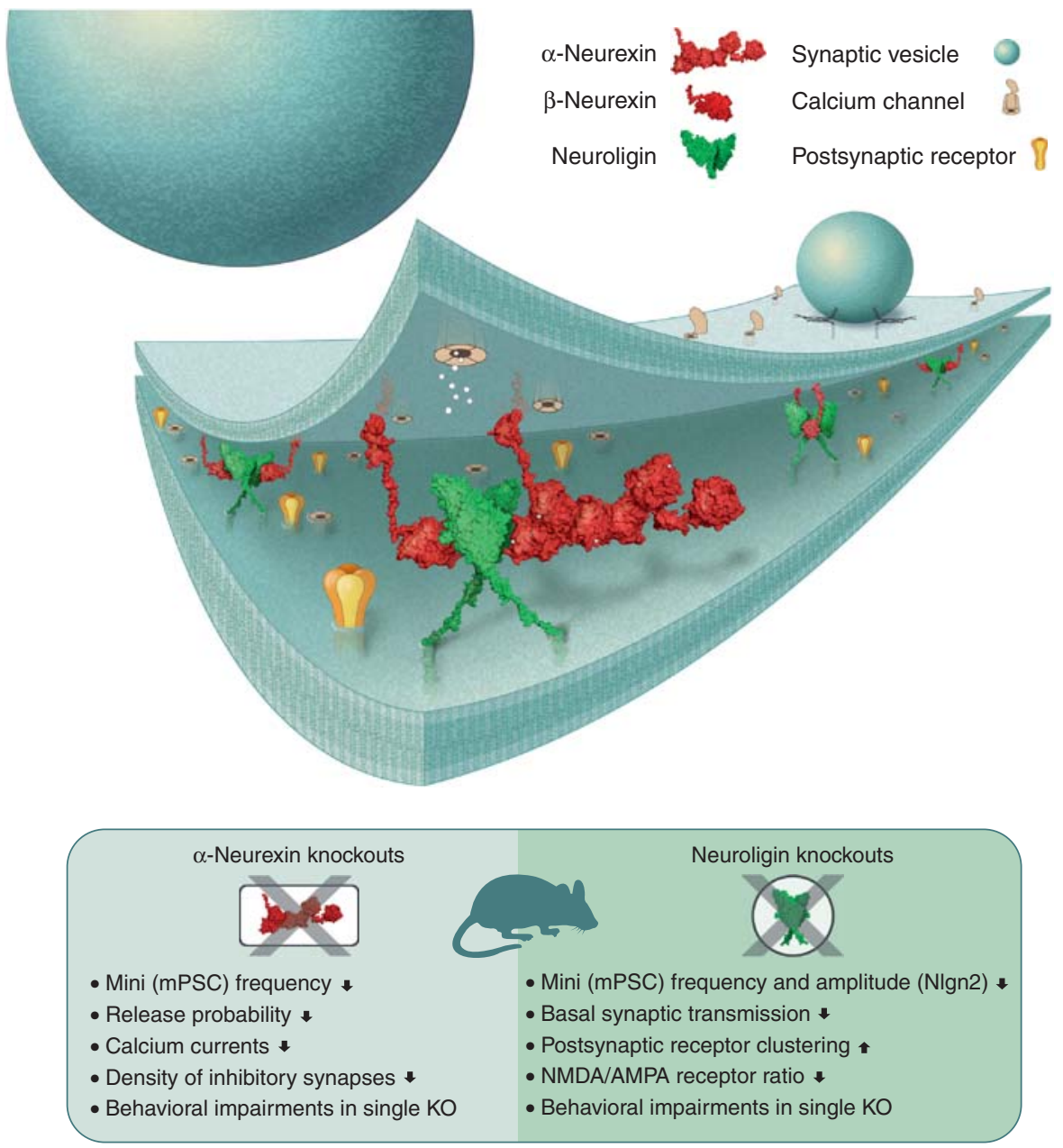

Figure 2. The case of neurexins/neuroligins. Presynaptic neurexins (red) and postsynaptic neuroligin dimers (green) associate in a $\mathrm{Ca}^{2+}$-dependent manner to form a prototypical trans-synaptic complex that reflects the asymmetric architecture of chemical synapses. The sixth LNS domain of $\alpha$-neurexins and the corresponding single LNS domain of $\beta$-neurexins both bind to neuroligins via hydrophobic interactions that bury the $\mathrm{Ca}^{2+}$-ion in the interface. Genetic deletion studies in mice revealed the essential role of both gene families at synapses because triple knockouts of either neurexin- $1 \alpha / 2 \alpha / 3 \alpha$ or of neuroligin- $1 / 2 / 3$ are perinatally lethal, and show dramatic impairments in synaptic function as summarized in the text box (arrows indicate direction of change). Note that $\alpha$-neurexins and neuroligins are not essential for the formation of synaptic contacts in the brain. The space filling models of the extracellular sequences of neurexins and neuroligins are based on homology modeling of available crystal data, and are presented approximately to scale in the synaptic cleft. (Full-length structures of synaptic cell adhesion proteins and of postsynaptic receptors as shown in Figures 2-4 were modeled using coordinates from the protein data bank (http://www.pdb.org), models from ModBase (http://modbase.compbio.ucsf.edu), SWISS-MODEL Repository (http://swissmodel.expasy.org/repository/) and Phyre (http://www.sbg.bio.ic.ac.uk/ phyre/). Missing structures were modeled manually using BLAST2MODEL (http://dunbrack.fccc.edu) and program SPDPV (http://spdbv.vital-it.ch/). The complex structures were visualized using the open source program pymol (http://sourceforge.net/projects/pymol/). 
M. Missler et al.

As summarized below, the same site of alternative splicing is also of central importance for the interactions of neurexins with other ligands.

Cell-based assays of synapse assembly showed that contact of dissociated neurons with neuroligin-expressing nonneuronal cells results in the recruitment of presynaptic markers (Scheiffele et al. 2000), whereas contact of neurons with neurexin-expressing nonneuronal cells produces recruitment of postsynaptic markers (Graf et al. 2004; Nam and Chen 2005). The activity of neuroligin in this artificial synapse formation assay depends on binding to its presynaptic partner neurexin (Ko et al. 2009a). Although this cellbased assay does not differentiate between synapse-inducing and synapse-stabilizing activities of a molecule, it provides a powerful approach to dissecting the structure/function relationships of synaptic cell adhesion molecules.

Interestingly, overexpression of neuroligins in neurons leads to dramatic increases in neuronal synapse density (Chih et al. 2005; Boucard et al. 2005), with specific effect of neuroligin-1 on excitatory and neuroligin-2 on inhibitory synapses (Chubykin et al. 2007). The increased synapse density induced by neuroligin overexpression likely reflects a stabilization of transient synaptic contacts by neuroligins because it is activity-dependent (Chubykin et al. 2007; Ko et al. 2011). Similar changes were also observed upon transgenic overexpression of neuroligins in mice (Hines et al. 2008; Dahlhaus et al. 2010), whereas deletion of neuroligins does not decrease synapse density (Varoqueaux et al. 2006; see discussion below). At least in the case of neuroligin-1, the increase in neuronal synapse density induced by overexpression is independent of the cytoplasmic tail of neuroligin-1, its dimerization, or its binding to neurexins (Ko et al. 2009a, 2011).

Studies of knockout mice have revealed vital functions for $\alpha$-neurexins and neuroligins in organizing synapses. The combined knockout of all three $\alpha$-neurexins is lethal at birth, likely because of a strong impairment in neurotransmitter release (Fig. 2) (Missler et al. 2003; Zhang et al. 2005a). Specifically, triple $\alpha$-neurexin knockout mice showed an almost complete abatement of glutamatergic synaptic transmission in acute brainstem slices and in cultured cortical slices, but no significant decrease in glutamatergic synapse density (Missler et al. 2003). Survival of $\alpha$-neurexin double-knockout mice is also compromised, and animals reaching adulthood show lowered inhibitory synapse densities, whereas excitatory synapse numbers remain unchanged (Missler et al. 2003). Even single $\alpha$-neurexin knockout mice show a survival phenotype, and neurexin- $1 \alpha$ single knockout mice display decreased excitatory transmission in the hippocampus and behavioral deficits (Etherton et al. 2009). In addition, the triple $\alpha$-neurexin knockout mice show changes in postsynaptic NMDA receptor function (Kattenstroth et al. 2004), and neurexins physically bind to $\mathrm{GABA}_{\mathrm{A}}$-receptors and acetylcholine receptors (Cheng et al. 2009; Zhang et al. 2010). Despite this wealth of information, however, the precise role of neurexins remains incompletely understood; although the data are best explained by an organizing function of neurexins in coordinating the recruitment of calcium channels and components of the release machinery to presynaptic terminals with the assembly of postsynaptic specializations, the molecular mechanisms involved remain uncharacterized. As we will see below, one reason for this uncertainty is the bewildering number of extracellular trans-synaptic interaction partners for neurexins that extend beyond neuroligins - themselves central players in synapse organization-to proteins such as leucinerich repeat transmembrane proteins (LRRTMs), cerebellins, and dystroglycan.

Triple knockout of NL1, NL2, and NL3 also results in perinatal lethality caused by an impairment of transmission (Varoqueaux et al. 2006). Similar to the triple $\alpha$-neurexin knockout, the triple neuroligin knockout has no major effect on overall synapse numbers, again supporting a role of this protein family in organizing synapses. Consistent with its localization, the single knockout of NL1 selectively impairs the strength of excitatory synapses and decreases the ratio of NMDA- to AMPA-receptor mediated responses, whereas single knock out of NL2 selectively depresses inhibitory synaptic transmission (Chubykin et al. 2007; Poulopoulos et al. 2009). Interestingly, paired recordings in the somatosensory cortex revealed 
that the NL2 knockout does not affect all inhibitory synapses equally, but selectively only dampened inputs from fast-spiking interneurons without decreasing connectivity (Gibson et al. 2009). Thus, NL2 does not function as a general organizer of all inhibitory synapses, but acts in a selected subset of inhibitory synapses in a neuron. Studies in Drosophila, Caenorhabditis elegans, and Aplysia support the notion that neurexins and neuroligins control synapse morphology and composition, at least in invertebrates (Li et al. 2007; Banovic et al. 2010; Choi et al. 2011; Haklai-Topper et al. 2011; Sun et al. 2011).

In contrast to knockout studies, RNAi-mediated knockdowns have suggested in some cases that acute loss-of-function of a single neurexin and neuroligin isoform results in a dramatic loss of synapses in rodent neurons (e.g. see Chih et al. 2003; de Wit et al. 2009; Shipman et al. 2011). However, other studies found no effect of RNAi-mediated knockdown of single or multiple neuroligin isoforms on synapse density (Ko et al. 2011; Zhang et al. 2010), even when performed in vivo (Soler-Llavina et al. 2011). A potential problem with RNAi-mediated knockdown experiments are off-target effects, as shown for example for knockdown of LRRTMs (Ko et al. 2011). A further issue in RNAi-mediated knockdowns of neuroligins, LRRTMs, and similar molecules is that classical rescue experiments are not possible because overexpression of the target molecules used for rescue by itself causes a gain-of-function phenotype. It is possible that genetic knockouts of neuroligins and $\alpha$-neurexins are partly developmentally compensated, such that some phenotypes are not present in constitutive knockouts (such as a loss of synapses) whereas others are (such as a loss of synaptic function). Conditional knockout mice are now being generated to test this possibility.

\section{OTHER LIGANDS FOR NEUREXINS AND NEUROLIGINS}

Neurexins and neuroligins not only interact with each other, but also with other proteins (Fig. 3). Neurexins bind to at least two other synapse-organizing proteins, the LRRTM membrane pro- teins that induce presynaptic terminals in hippocampal neurons (de Wit et al. 2009; Ko et al. 2009b; Siddiqui et al. 2010) and to cerebellins that participate in synapse formation at least in Purkinje cells (Uemura et al. 2010; Matsuda and Yuzaki 2011). The binding of LRRTMs to neurexins is competitive with neuroligins because the binding site partly overlaps, and is tightly regulated by alternative splicing at splice site \#4 (Fig. 3) (Ko et al. 2009b; Siddiqui et al. 2010). Binding of cerebellins to neurexins is also controlled by alternative splicing at site 4 , but here an insert in splice site 4 is required for binding to cerebellins (Uemura et al. 2010; Matsuda and Yuzaki 2011). Morever, $\mathrm{Ca}^{2+}$ is required for binding of neurexins to neuroligins and LRRTMs (Ichtchenko et al. 1995; Ko et al. 2009b), but not for binding of neurexins to cerebellins (Uemura et al. 2010; Matsuda and Yuzaki 2011).

Recent systematic studies explored the importance of the neurexin-binding partners neuroligin-1 and -3 vs. LRRTM2 and LRRTM3 at excitatory synapses in cultured neurons (Ko et al. 2011) and in vivo (Soler-Llavina et al. 2011). Only a combined loss-of-function of neuroligin-1 and -3 (which are the only neuroligins at excitatory synapses) and LRRTM2 and LRRTM3 (which are the only LRRTMs expressed at significant levels in the hippocampal neurons examined) suppressed excitatory but not inhibitory synapse densities in cultured neurons but not in vivo. Interestingly, the decrease in synapse density induced by the loss-of-function of neuroligins and LRRTMs in cultured neurons was completely activity-dependent, similar to the increase induced by overexpression (Ko et al. 2011). In these experiments, "knockdown" neurons were in a competition for synapses with surrounding wild-type neurons. Overall, these experiments together with the knockout data suggest that neurexin ligands do not act as synaptic glues, but as cell-autonomous, activitydependent regulators of synapse function, with their dysfunction leading to synapse elimination in some circumstances.

$\alpha$-Neurexins also bind to dystroglycan, which is abundantly expressed in neurons (Sugita et al. 2001), and to the neuropeptide-like protein 
M. Missler et al.

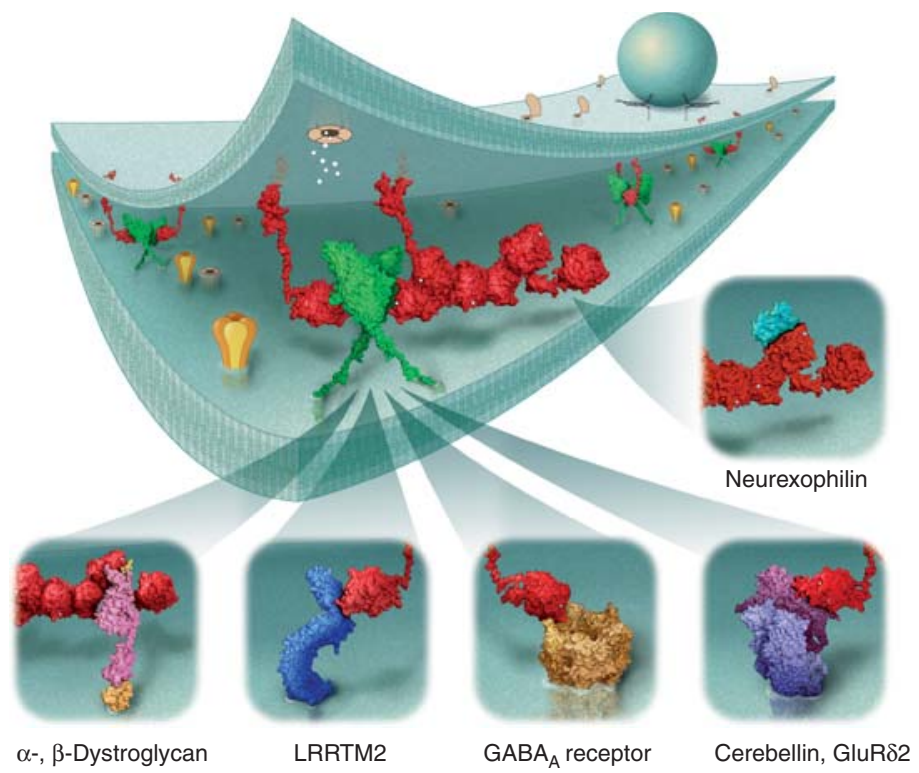

Figure 3. Neurexins as synaptic anchors for macromolecular complexes. Because of the versatile nature of their LNS domains, $\alpha$ - and $\beta$-neurexins can interact with several binding partners (see insets) that either compete for the same interaction site such as neuroligin-1 and LRRTM2, or may bind at completely different sites such as neurexophilin. Because neuroligins form dimers, mixed complexes of $\alpha$ - and $\beta$-neurexins with neuroligin may exist, and may even recruit additional binding partners of $\alpha$-neurexins, possibly leading to large multimolecular clusters. Direct or indirect association with ligand- or voltage-dependent ion channels (e.g., GABA $\mathrm{A}_{\mathrm{A}}$, GluR, NMDAR, $\mathrm{Ca}_{\mathrm{V}} 2 . \mathrm{x}$, see text for discussion) provides a means of determining synaptic properties or modulating synaptic strength. The space filling models of neurexins and their binding partners are based on homology modeling of available crystal data, and are presented approximately to scale in the synaptic cleft.

neurexophilin (Missler et al. 1998). Both interact with the second LNS domain of $\alpha$-neurexins. Moreover, neuroligins exert neurexin-independent synapse-organizing functions (Ko et al. 2009a; Banovic et al. 2010) suggesting that additional synaptic partners for neuroligins must exist.

\section{CADHERINS INFLUENCE EARLY SYNAPSE DEVELOPMENT AND IMPACT SYNAPTIC PLASTICITY}

Classical cadherins are among the best-studied adhesion molecules and also contribute to synaptic cell adhesion. They contain five extracellular cadherin repeat domains (EC1-5), with the amino-terminal EC1 domain mediating adhesion in trans (Fig. 4) (Pokutta and Weis 2007). $\mathrm{N}$-cadherin, the most prominent classical cad- herin in brain, is localized to sites surrounding synapses (Uchida et al. 1996). It does not control synapse number and is not involved in synapse formation as such but likely plays broad modulatory roles in synapse development (Jüngling et al. 2006). N-cadherin accumulates at nascent synapses with a delay after axo-dendritic contact (Benson and Tanaka 1998), and contributes to the structural maturation of postsynaptic sites through catenin signaling (Togashi et al. 2002; Bamji et al. 2003; Elia et al. 2006). Synaptic activity drives $\mathrm{N}$-cadherin into spines, the postsynaptic elements of excitatory synapses, and stabilizes the structural changes that occur during LTP in developing and mature synapses (Bozdagi et al. 2010; Mendez et al. 2010). This homophilic adhesion molecule also acts across the synaptic cleft to modulate presynaptic plasticity (Jüngling et al. 2006) and 
Synaptic Cell Adhesion
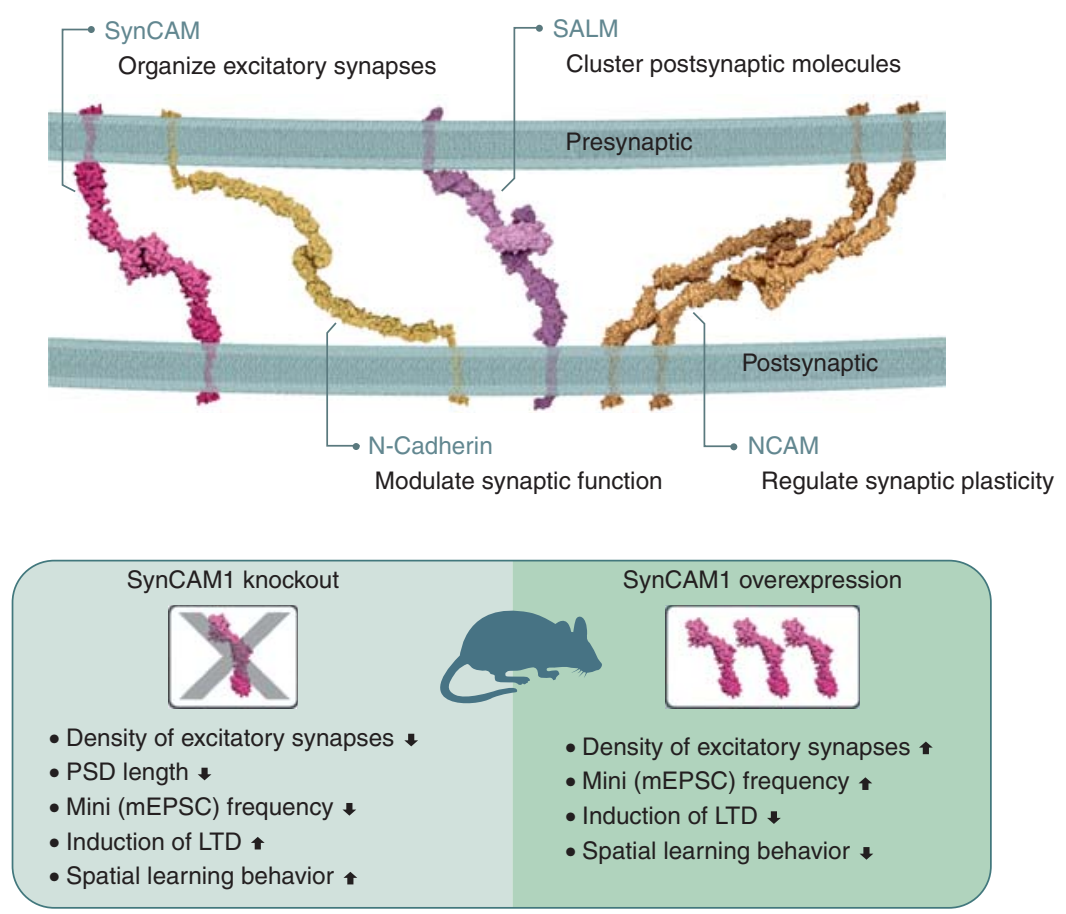

Figure 4. Complexes by synaptic cell adhesion molecule families. Trans-synaptic complexes also occur between members of the same synaptic cell adhesion molecule family. The examples shown here contain multimers of characteristic extracellular domains such as Ig-domains (e.g., in SynCAM), EC domains (e.g., in N-cadherin), or LRR repeats (e.g., in SALM). The actual combinatorial code is not always as simple as depicted in the diagram because homomeric as well as heteromeric (e.g., SynCAM 1-SynCAM 2) binding occurs, and there are instances in which synaptic cell adhesion molecules act without formation of a known bona fide trans-synaptic complex (e.g., in SALMs, or NCAMs). Complexes between members of synaptic cell adhesion molecule family affect diverse aspects of synaptic function and plasticity. Although none of these gene families is essential for the establishment of the majority of synaptic contacts in the brain, analyses of SynCAM 1 knockout and transgenic mice have pointed to an essential role in the formation of excitatory synapses as summarized in the text box below the synapse diagram (arrows indicate direction of change). The space filling models are presented approximately to scale.

reduced presynaptic $\mathrm{N}$-cadherin adhesion alters synaptic vesicle recycling (Togashi et al. 2002). The synaptic functions of $\mathrm{N}$-cadherin complement other properties of classical cadherins in neuronal development, such as their cosegregation with motor neuron pools that is indicative of conveying neuronal identity and may contribute to neuronal connectivity (Price et al. 2002).

Although $\mathrm{N}$-cadherin is the best-studied member of the cadherin family at synapses, other cadherin-related proteins are also likely important for synapse assembly and function. In Drosophila, a GPCR of this cell adhesion family called flamingo (vertebrate homolog: CELSR) contains multiple cadherin repeats and has been implicated in specifying planar cell polarity and synapse specificity (Formstone 2010). Protocadherins constitute a large and diverse protein family with ubiquitously expressed members that may also be present, at least in part at synapses. For example $\boldsymbol{\gamma}$-protocadherins are at least partly synaptic (Phillips et al. 2003), and are required for the postnatal survival of interneurons in the spinal cord (Wang et al. 2002). This phenotype of neuronal lethality could be alleviated by impairing apoptosis, allowing to show that the loss of the $\gamma$-protocadherin gene 
M. Missler et al.

cluster leads to synaptic deficits in mouse spinal cord (Weiner et al. 2005). Similarly, calsyntenins are cadherin-related proteins that are enriched in postsynaptic densities, although their functions remain uncharacterized (Hintsch et al. 2002).

\section{SynCAM, LAR-TYPE RECEPTOR PHOSPHOTYROSINE PHOSPHATASES, AND OTHER IG-DOMAIN PROTEINS}

Many Ig-domain proteins have been localized to synapses, with the most conclusive evidence provided for a synaptic role of SynCAMs and of receptor phosphotyrosine phosphatases belonging to the LAR family.

SynCAM synaptic cell adhesion molecules (also named Cadm or nectin-like molecules) promote excitatory but not inhibitory synapse numbers (Fig. 4). The four members of this vertebrate-specific gene family contain three extracellular Ig-domains, a single transmembrane region, and intracellular FERM- and PDZ-domain-binding motifs whose similarities to those of neurexins led to SynCAM identification (Biederer et al. 2002; Biederer 2006). SynCAM proteins are predominantly expressed in the brain and localize to pre- and postsynaptic sites (Biederer et al. 2002; Thomas et al. 2008).

SynCAM 1 localizes in developing neurons to the surface of axonal growth cones and shapes them through its partner focal adhesion kinase (Nozumi et al. 2009; Stagi et al. 2010). Analogous to a "contact sensor" of growth cones, SynCAM 1 assembles rapidly at axo-dendritic contacts into stable adhesion complexes, which then accumulate synaptic markers (Stagi et al. 2010). At maturing synapses, SynCAM proteins form specific homo- and heterophilic complexes through their Ig-domains whose adhesive strength is regulated by site-specific $\mathrm{N}$ glycans, including sialic acid; and postsynaptic SynCAMs act across the synaptic cleft to promote functional excitatory synapse number (Fogel et al. 2007, 2010). Elevated SynCAM 1 increases the number of functional excitatory synapses in a transgenic mouse model, and synaptic SynCAM adhesion additionally mediates synapse maintenance (Robbins et al. 2010). Conversely, the loss of SynCAM 1 reduces excita- tory synapse number and transmission and shortens synaptic membrane specializations. At mature synapses, SynCAM 1 negatively regulates long-term depression and impacts spatial learning. Roles of SynCAM 1 in the wiring and plasticity of neuronal networks are supported by its unusually dynamic expression in the visual cortex during adaptive changes of eye-specific responses (Lyckman et al. 2008) and during the restoration of synapses by spinal cord motoneurons following injury (Zelano et al. 2009). The functions of other SynCAM family members in the brain remain to be analyzed, but the tight binding of SynCAM 2 to SynCAM 1, the ability of SynCAM 2 to induce synapses, and the presence of SynCAM 3/nectin-like molecule 1 at axon terminal/glia cell contacts (Kakunaga et al.2005) point to partially overlapping roles in synapse development.

Nectins are a family of Ig-domain adhesion proteins that share the extracellular domain organization of SynCAM molecules but have different cytosolic partners. Asymmetric interactions of nectins promote the formation of puncta adherentia, adhesion sites similar to tight junctions that likely provide mechanical stability at parasynaptic sites and at connections of spines to astrocytic processes, but the participation of nectins in synapses remains to be elucidated (Mizoguchi et al. 2002; Togashi et al. 2006).

Receptor phospho-tyrosine phosphatases (RPTPs) of the LAR family include LAR (leukocyte-associated receptor), RPTPo, and RPTP $\delta$ (Chagnon et al. 2004). Their extracellular domains are composed of three Ig-domains and eight fibronectin type III repeats. LAR-type RPTPs have been implicated in synapse formation via binding to their intracellular interaction partner $\alpha$-liprin, although alternatively a presynaptic site of action (Zhen and Yin 1999; Kaufmann et al. 2002) and a postsynaptic site of action was suggested (Dunah et al. 2005). Extracellularly, two trans-synaptic ligands were described for this class of RPTPs, in both cases suggesting a presynaptic localization of the RPTP: netrin-G ligands (Woo et al. 2009; see description under LRR proteins below) and the neurotrophin receptor TrkC (Takahashi et al. 2011). 
In addition to SynCAMs and RPTPs, other Ig-domain proteins such as contactins and members of the NCAM/L1 family have been implicated in synapse formation and function (reviewed in the work of Dityatev et al. 2008; Zuko et al. 2011). Presynaptically, NCAM isoforms play important roles at developing neuromuscular junctions, in which they control the distribution of release sites (Polo-Parada et al. 2004) and promote the physiological maturation of vesicle recycling (Hata et al. 2007). Postsynaptically, NCAM clustering influences the assembly of cytoskeletal scaffolds (Sytnyk et al. 2006) and contributes to LTP (Muller et al. 1996).

Finally, an important additional role of cell adhesion is to instruct where synaptic sites are formed. Several Ig-domain proteins have been implicated in this role. For example, such an instructive role is mediated in the retina by the sidekicks and Dscam Ig-domain proteins, which ensure proper lamina connectivity (Yamagata et al. 2002, 2008). Similarly, in C. elegans the Ig-domain proteins Syg-1 and Syg-2 are not directly related to synapse formation, but guide synapse formation to the right place in one particular neuron (Shen et al. 2004). In a comparable manner, adhesive interactions mediated by the Ig proteins neurofascin and CHL1 spatially define synapses formed by basket interneurons and stellate cell axons, respectively, onto Purkinje cells on a subcellular level (Ango et al. 2004, 2008).

\section{LEUCINE-RICH REPEAT PROTEINS ORGANIZE BOTH PRE- AND POSTSYNAPTIC SITES}

Several families of LRR proteins were shown to function at synapses, in particular LRRTMs, netrin-G ligands (NGLs), and synaptic adhesion-like molecules (SALMs, also known as Lrfn proteins).

Netrin-G1 and -G2 are netrin isoforms unique to vertebrates that are attached to axonal membranes by a GPI anchor (Nakashiba et al. 2002). As indicated by their name, NGLs were identified by binding to netrin-G1 (Lin et al. 2003), and are also called LRRC4 (Zhang et al. 2005b). The three vertebrate NGLs (NGL1-3) are type I membrane proteins composed of an extracellular LRR sequence, a single Ig-domain, a transmembrane region, and a short cytoplasmic tail capable of binding PSD-95 (Woo et al. 2009). NGLs are localized to postsynaptic membranes, in which NGL1 and NGL2 are thought to interact with presynaptic netrin-G1 and -G2 (Kim et al. 2006), and NGL3 with LAR-type RPTPs (Woo et al. 2009). Mice lacking either netrin-G2 or NGL2 show mild behavioral defects but are viable and fertile, indicating that the netrinG/NGL system may serve primarily as a modulatory signaling system for synapses (Zhang et al. 2008).

A possible synaptogenic function of LRRTMs, which were identified by bioinformatics (Laurén et al. 2003), was discovered in a systematic screen for synaptogenic proteins using the artificial synapse formation assay (Linhoff et al. 2009). Strikingly, protein-interaction studies subsequently revealed that LRRTMs bind to neurexins in a splice-site 4-dependent manner (see discussion above; de Wit et al. 2009; Ko et al. 2009b; Siddiqui et al.2010). Single knockout of LRRTMs has only minor phenotypes (Linhoff et al. 2009), and knockdown of all major LRRTMs expressed in a particular type of neuron in vitro or in vivo does not produce a loss of synapses, but decreases AMPA-receptor dependent trafficking (Ko et al. 2011; Soler-Llavina et al. 2011). As described above, the loss of synapses reported for one LRRTM2 shRNA construct (de Wit et al. 2009; Ko et al. 2011) likely reflects an off-target effect.

A third family of LRR-containing membrane proteins with synapse-organizing functions in vertebrates are SALMs (reviewed in Nam et al. 2011). Five SALM genes are expressed in vertebrates. SALMs are type I membrane proteins composed of an amino-terminal LRR domain, a single Ig-domain and fibronectin III domain, a transmembrane region and a cytoplasmic tail that binds to PSD-95 for SALM13, but not SALM4 and SALM5 (Ko et al. 2006; Wang et al. 2006). On the extracellular side, SALM4 and SALM5 form homophilic complexes (Seabold et al. 2008), and at least a subset of SALMs may interact with AMPA- and/or 
M. Missler et al.

NMDA-type glutamate receptors (Ko et al. 2006; Wang et al. 2006). Moreover, SALMs may influence neuronal development and neurite outgrowth, but the precise role of SALMs in synapses remains unclear.

\section{TYROSINE KINASE RECEPTOR SIGNALING IN EXCITATORY SYNAPSE DEVELOPMENT}

In addition to classical adhesion molecules, transmembrane tyrosine kinase receptors have been implicated in synapse formation. Notably, EphB receptor tyrosine kinases are thought to produce a postsynaptic signal upon extracellular binding of their ephrin ligands, and to engage several small Rho family GTPases, including RhoA and Rac1, as a result, thereby remodeling the actin cytoskeleton of postsynaptic spines (Lai and Ip 2009). The combined deletion of EphB1-3 receptors in mice strongly reduces synapse density and alters the morphology of dendritic spines (Henkemeyer et al.2003). A synapse-inducing role of EphB receptors was corroborated in cultured hippocampal neurons. EphB2 receptor signaling from postsynaptic sites triggers presynaptic differentiation through ephrin binding, which stabilizes a subset of synapses (Kayser et al. 2006). Similarly, postsynaptic EphB2 receptors engage presynaptic ephrinB ligands to induce and mature retinotectal synapses in Xenopus (Lim et al. 2008). EphB2 additionally may organize postsynaptic membranes in cis through lateral interactions with NMDA receptors (Dalva et al. 2000). However, transmembrane ephrin ligands were also shown to be present at excitatory postsynaptic sites where they promote spine density and maturation and AMPA receptor trafficking (Segura et al. 2007). Moreover, postsynaptic ephrinB3 ligand in addition controls the number of dendritic shaft synapses, a subset of excitatory synapses (Aoto et al. 2007). The activation of postsynaptic EphA receptors, which bind the GPI-anchored ephrinA ligands expressed in astrocytes, in contrast leads to spine retraction (Murai et al. 2003; Bourgin et al. 2007). Overall, it seems likely that Ephrin/Eph receptor interactions are major determinants of synaptic function via cytoskeletal reorganizations, a role that they also perform in many other cellular processes, and the specific trans-synaptic roles of ephrin/Eph receptor interactions remain to be elucidated.

Other transmembrane receptor tyrosine kinases share important functions at excitatory synapses. These include Trk receptors, which mediate neurotrophin signaling and are necessary for proper synapse density and ultrastructure, and modulate activity-dependent structural and functional changes at synapses (Rico et al. 2002; Luikart et al. 2005; Rex et al. 2007), in addition to their noncatalytic role mediated by binding to LAR-type RPTPs (Takahashi et al. 2011; see above). Signaling by the insulin receptor also promotes synapse number and function as shown in the Xenopus optic tectum and alters dendrite dynamics (Chiu et al. 2008). Another family of receptor tyrosine kinases, the ErbB receptors, is known to act in the formation of neuromuscular junctions. Roles in central synapses are emerging, with the ErbB4 ligand neuregulin-1 enhancing GABA release from cortical interneurons (Woo et al. 2007).

\section{ADDITIONAL SURFACE INTERACTIONS REGULATE SYNAPSE DEVELOPMENT AND PHYSIOLOGY}

Integrins are another prominent class of adhesion molecules that promote synapse maturation (Chavis and Westbrook 2001). Integrins also impact synaptic physiology as loss of their $\beta 1$ subunit impairs LTP (Chan et al. 2006; Huang et al. 2006). Trans-synaptic interactions are not limited to classic adhesion molecules, though, as shown by the neuronal pentraxins. This protein family binds extracellularly to AMPA receptors and can form trans-synaptic complexes to organize excitatory synapse development (O’Brien et al. 2002; Koch et al. 2010).

\section{SYNAPTIC CELL ADHESION AND BRAIN DISORDERS}

Studies of synapse structure have not only provided crucial keys to understanding synapse development. They have also shown that the altered morphology of excitatory synapses can be 
Synaptic Cell Adhesion

linked to neurological and neurodevelopmental disorders. Human genetic analyses of autismspectrum disorders both in hereditary cases and through genome-wide association studies point to a synaptic etiology. These analyses have established strong genetic links of mutations in synaptic cell adhesion molecules to autism-spectrum disorders, notably in neuroligins and neurexins (reviewed in Südhof 2008). In the case of two autism-linked neuroligin mutations, mouse models have corroborated the human genetic findings (Tabuchi et al. 2007; Jamain et al. 2008). These results endorse the hypothesis that neurodevelopmental disorders can stem from synapse disorganization and imbalanced neuronal excitation and inhibition (Zoghbi 2003; Bourgeron 2009). Studies of synaptic cell adhesion are therefore likely to contribute importantly to understanding both synaptic biology and human brain disorders.

\section{CONCLUDING REMARKS: FOUR OPEN QUESTIONS}

Synapse formation requires mechanisms that demarcate and align future synaptic sites, and differentiate nascent synapses into maturity. As reviewed in this work, a select group of synaptic cell adhesion and signaling proteins organizes these processes. However, we are only at the beginning of an understanding of how synapses are formed and maintained. Four key questions stand out. First, do individual synapse-organizing proteins actually instruct synaptic cell adhesion in vivo, or do the functions of transsynaptic interactions result from cooperativity among different adhesion molecules? Second, how do these trans-synaptic interactions act at mature synapses to alter plasticity and maintenance? Third, is the functional role of synapseorganizing molecules strictly defined, or does it change during the lifetime of a synapse? Fourth, which intracellular signaling pathways do these proteins engage? Addressing these questions will integrate our understanding of how synaptic cell adhesion molecules guide synapse development and the plasticity of mature synapses and how altered synaptic cell adhesion can underlie brain disorders.

\section{ACKNOWLEDGMENTS}

We thank H. Blum and C. Reissner for help with illustrations, and members of the Biederer laboratory and C.R. for comments on the manuscript. Work on synaptic cell adhesion molecules in the authors' laboratories are supported by grants from the NIH (grant R01 DA018928 to T.B., and R01MH089054 and R37 MH052804 to T.C.S.), the Simons Foundation (SF177850 to T.C.S.), and the DFG (SFB 492-A16 to M.M.).

\section{REFERENCES}

Akins MR, Biederer T. 2006. Cell-cell interactions in synaptogenesis. Curr Opin Neurobiol 16: 83-89.

Ango F, di Cristo G, Higashiyama H, Bennett V, Wu P, Huang ZJ. 2004. Ankyrin-based subcellular gradient of neurofascin, an immunoglobulin family protein, directs GABAergic innervation at purkinje axon initial segment. Cell 119: 257-272.

Ango F, Wu C, Van der Want JJ, Wu P, Schachner M, Huang ZJ. 2008. Bergmann glia and the recognition molecule CHL1 organize GABAergic axons and direct innervation of Purkinje cell dendrites. PLoS Biol 6: e103.

Aoto J, Ting P, Maghsoodi B, Xu N, Henkemeyer M, Chen L. 2007. Postsynaptic EphrinB3 promotes shaft glutamatergic synapse formation. J Neurosci 27: 7508-7519.

Araç D, Boucard AA, Özkan E, Strop P, Newell E, Südhof TC, Brunger AT. 2007. Structures of Neuroligin-1 and the Neuroligin-1/Neurexin-1 $\beta$ complex reveal specific protein-protein and protein- $\mathrm{Ca}^{2+}$ interactions. Neuron 56: 992-1003.

Bamji SX, Shimazu K, Kimes N, Huelsken J, Birchmeier W, Lu B, Reichardt LF. 2003. Role of $\beta$-catenin in synaptic vesicle localization and presynaptic assembly. Neuron 40: $719-731$.

Banovic D, Khorramshahi O, Owald D, Wichmann C, Riedt T, Fouquet W, Tian R, Sigrist SJ, Aberle H. 2010. Drosophila neuroligin 1 promotes growth and postsynaptic differentiation at glutamatergic neuromuscular junctions. Neuron 66: 724-738.

Benson DL, Tanaka H. 1998. N-Cadherin redistribution during synaptogenesis in hippocampal neurons. J Neurosci 18: 6892-6904.

Biederer T. 2006. Bioinformatic characterization of the SynCAM family of immunoglobulin-like domain-containing adhesion molecules. Genomics 87: 139-150.

Biederer T, Südhof TC. 2001. CASK and protein 4.1 support F-actin nucleation on neurexins. J Biol Chem 276: 47869-47876.

Biederer T, Sara Y, Mozhayeva M, Atasoy D, Liu X, Kavalali ET, Südhof TC. 2002. SynCAM, a synaptic adhesion molecule that drives synapse assembly. Science 297: 1525-1531.

Boucard AA, Chubykin AA, Comoletti D, Taylor P, Südhof TC. 2005. A splice code for trans-synaptic cell adhesion mediated by binding of neuroligin 1 to $\alpha$ - and $\beta$-neurexins. Neuron 48: 229-236. 
M. Missler et al.

Bourgeron T. 2009. A synaptic trek to autism. Curr Opin Neurobiol 19: 231-234.

Bourgin C, Murai KK, Richter M, Pasquale EB. 2007. The EphA4 receptor regulates dendritic spine remodeling by affecting $\beta 1$-integrin signaling pathways. J Cell Biol 178: 1295-1307.

Bozdagi O, Wang XB, Nikitczuk JS, Anderson TR, Bloss EB, Radice GL, Zhou Q, Benson DL, Huntley GW. 2010. Persistence of coordinated long-term potentiation and dendritic spine enlargement at mature hippocampal CAl synapses requires N-cadherin. J Neurosci 30: 9984-9989.

Budreck EC, Scheiffele P. 2007. Neuroligin-3 is a neuronal adhesion protein at GABAergic and glutamatergic synapses. Eur J Neurosci 26: 1738-1748

Chagnon MJ, Uetani N, Tremblay ML. 2004. Functional significance of the LAR receptor protein tyrosine phosphatase family in development and diseases. Biochem Cell Biol 82: 664-675.

Chan CS, Weeber EJ, Zong L, Fuchs E, Sweatt JD, Davis RL. 2006. $\beta$ 1-integrins are required for hippocampal AMPA receptor-dependent synaptic transmission, synaptic plasticity, and working memory. J Neurosci 26: 223-232.

Chavis P, Westbrook G. 2001. Integrins mediate functional pre- and postsynaptic maturation at a hippocampal synapse. Nature 411: 317-321.

Chen F, Venugopal V, Murray B, Rudenko G. 2011. The structure of neurexin $1 \alpha$ reveals features promoting a role as synaptic organizer. Structure 19: 779-789.

Cheng SB, Amici SA, Ren XQ, McKay SB, Treuil MW, Lindstrom JM, Rao J, Anand R. 2009. Presynaptic targeting of $\alpha 4 \beta 2$ nicotinic acetylcholine receptors is regulated by neurexin-1ß. J Biol Chem 284: 23251-23259.

Chih B, Engelman H, Scheiffele P. 2005. Control of excitatory and inhibitory synapse formation by neuroligins. Science 307: 1324-1328.

Chih B, Gollan L, Scheiffele P. 2006. Alternative splicing controls selective trans-synaptic interactions of the neuroligin-neurexin complex. Neuron 51: 171-178.

Chiu SL, Chen CM, Cline HT. 2008. Insulin receptor signaling regulates synapse number, dendritic plasticity, and circuit function in vivo. Neuron 58: 708-719.

Choi YB, Li HL, Kassabov SR, Jin I, Puthanveettil SV, Karl KA, Lu Y, Kim JH, Bailey CH, Kandel ER. 2011. Neurexinneuroligin transsynaptic interaction mediates learningrelated synaptic remodeling and long-term facilitation in aplysia. Neuron 70: 468-481.

Chubykin AA, Atasoy D, Etherton MR, Brose N, Kavalali ET, Gibson JR, Südhof TC. 2007. Activity-dependent validation of excitatory versus inhibitory synapses by neuroligin-1 versus neuroligin-2. Neuron 54: 919-931.

Cooper MW, Smith SJ. 1992. A real-time analysis of growth cone-target cell interactions during the formation of stable contacts between hippocampal neurons in culture. $J$ Neurobiol 23: 814-828.

Dahlhaus R, Hines RM, Eadie BD, Kannangara TS, Hines DJ, Brown CE, Christie BR, El-Husseini A. 2010. Overexpression of the cell adhesion protein neuroligin- 1 induces learning deficits and impairs synaptic plasticity by altering the ratio of excitation to inhibition in the hippocampus. Hippocampus 20: 305-322.
Dalva MB, Takasu MA, Lin MZ, Shamah SM, Hu L, Gale NW, Greenberg ME. 2000. EphB receptors interact with NMDA receptors and regulate excitatory synapse formation. Cell 103: 945-956.

de Wit J, Sylwestrak E, O'Sullivan ML, Otto S, Tiglio K, Savas JN, Yates JR III, Comoletti D, Taylor P, Ghosh A. 2009. LRRTM2 interacts with Neurexin1 and regulates excitatory synapse formation. Neuron 64: 799-806.

Dityatev A, Bukalo O, Schachner M. 2008. Modulation of synaptic transmission and plasticity by cell adhesion and repulsion molecules. Neuron Glia Biol 4: 197-209.

Dunah AW, Hueske E, Wyszynski M, Hoogenraad CC, Jaworski J, Pak DT, Simonetta A, Liu G, Sheng M. 2005. LAR receptor protein tyrosine phosphatases in the development and maintenance of excitatory synapses. Nat Neurosci 8: 458-467.

Elia LP, Yamamoto M, Zang K, Reichardt LF. 2006. p120 catenin regulates dendritic spine and synapse development through Rho-family GTPases and cadherins. Neuron 51: 43-56.

Etherton MR, Blaiss CA, Powell CM, Südhof TC. 2009. Mouse neurexin-1a deletion causes correlated electrophysiological and behavioral changes consistent with cognitive impairments. Proc Natl Acad Sci 42: 7998 8003.

Fogel AI, Akins MR, Krupp AJ, Stagi M, Stein V, Biederer T. 2007. SynCAMs organize synapses through heterophilic adhesion. J Neurosci 27: 12516-12530.

Fogel AI, Li Y, Giza J, Wang Q, Lam TT, Modis Y, Biederer T. 2010. N-glycosylation at the SynCAM immunoglobulin interface modulates synaptic adhesion. J Biol Chem 285: 34864-34874.

Formstone CJ. 2010. 7TM-Cadherins: Developmental roles and future challenges. Adv Exp Med Biol 706: 14-36.

Gibson JR, Huber KM, Südhof TC. 2009. Neuroligin-2 deletion selectively decreases inhibitory synaptic transmission originating from fast-spiking, but not from somatostatin-positive interneurons. J Neurosci 29: $13883-$ 13897.

Graf ER, Zhang X, Jin S-X, Linhoff MW, Craig AM. 2004. Neurexins induce differentiation of GABA and glutamate postsynaptic specializations via neuroligins. Cell 119: 1013-1026.

Gray EG. 1959. Axo-somatic and axo-dendritic synapses of the cerebral cortex: An electron microscope study. J Anat 93: $420-433$.

Gray EG, Whittaker VP. 1962. The isolation of nerve endings from brain: An electron-microscopic study of cell fragments derived by homogenization and centrifugation. $J$ Anat 96: 79-88.

Haklai-Topper L, Soutschek J, Sabanay H, Scheel J, Hobert O, Peles E. 2011. The neurexin superfamily of Caenorhabditis elegans. Gene Expr Patterns 11: 144-150.

Hata Y, Butz S, Südhof TC. 1996. CASK: A novel dlg/PSD95 homolog with an N-terminal calmodulin-dependent protein kinase domain identified by interaction with neurexins. J Neuro sci 16: 2488-2494.

Hata K, Polo-Parada L, Landmesser LT. 2007. Selective targeting of different neural cell adhesion molecule isoforms during motoneuron myotube synapse formation in 
culture and the switch from an immature to mature form of synaptic vesicle cycling. J Neurosci 27: 14481-14493.

Henkemeyer M, Itkis OS, Ngo M, Hickmott PW, Ethell IM. 2003. Multiple EphB receptor tyrosine kinases shape dendritic spines in the hippocampus. J Cell Biol 163: 1313-1326.

Hines RM, Wu L, Hines DJ, Steenland H, Mansour S, Dahlhaus R, Singaraja RR, Cao X, Sammler E, Hormuzdi SG, et al. 2008. Synaptic imbalance, stereotypies, and impaired social interactions in mice with altered neuroligin 2 expression. J Neurosci 28: 6055-6067.

Hintsch G, Zurlinden A, Meskenaite V, Steuble M, FinkWidmer K, Kinter J, Sonderegger P. 2002. The calsyntenins-a family of postsynaptic membrane proteins with distinct neuronal expression patterns. Mol Cell Neurosci 21: 393-409.

Hoon M, Soykan T, Falkenburger B, Hammer M, Patrizi A, Schmidt KF, Sassoè-Pognetto M, Löwel S, Moser T, Taschenberger H, et al. 2011. Neuroligin-4 is localized to glycinergic postsynapses and regulates inhibition in the retina. Proc Natl Acad Sci 108: 3053-3058.

Huang Z, Shimazu K, Woo NH, Zang K, Muller U, Lu B, Reichardt LF. 2006. Distinct roles of the $\beta 1$-class integrins at the developing and the mature hippocampal excitatory synapse. J Neurosci 26: 11208-11219.

Ichtchenko K, Hata Y, Nguyen T, Ullrich B, Missler M, Moomaw C, Südhof TC. 1995. Neuroligin 1: A splice site-specific ligand for $\beta$-neurexins. Cell 81: 435-443.

Ichtchenko K, Nguyen T, Südhof TC. 1996. Structures, alternative splicing, and neurexin binding of multiple neuroligins. J Biol Chem 271: 2676-2682.

Irie M, Hata Y, Takeuchi M, Ichtchenko K, Toyoda A, Hirao K, Takai Y, Rosahl TW, Südhof TC. 1997. Binding of neuroligins to PSD-95. Science 277: 1511-1515.

Jamain S, Radyushkin K, Hammerschmidt K, Granon S, Boretius S, Varoqueaux F, Ramanantsoa N, Gallego J, Ronnenberg A, Winter D, et al. 2008. Reduced social interaction and ultrasonic communication in a mouse model of monogenic heritable autism. Proc Natl Acad Sci 105: 1710-1715.

Jüngling K, Eulenburg V, Moore R, Kemler R, Lessmann V, Gottmann K. 2006. N-cadherin transsynaptically regulates short-term plasticity at glutamatergic synapses in embryonic stem cell-derived neurons. J Neurosci 26: 6968-6978.

Kakunaga S, Ikeda W, Itoh S, Deguchi-Tawarada M, Ohtsuka T, Mizoguchi A, Takai Y. 2005. Nectin-like molecule-1/TSLL1/SynCAM3: A neural tissue-specific immunoglobulin-like cell-cell adhesion molecule localizing at non-junctional contact sites of presynaptic nerve terminals, axons and glia cell processes. J Cell Sci 118: 12671277.

Kattenstroth G, Tantalaki E, Südhof TC, Gottmann K, Missler M. 2004. Postsynaptic N-methyl-D-aspartate receptor function requires $\alpha$-neurexins. Proc Natl Acad Sci 101: 2607-2612.

Kaufmann N, DeProto J, Ranjan R, Wan H, Van Vactor D. 2002. Drosophila liprin- $\alpha$ and the receptor phosphatase Dlar control synapse morphogenesis. Neuron 34: 27-38.

Kayser MS, McClelland AC, Hughes EG, Dalva MB. 2006. Intracellular and trans-synaptic regulation of glutamater- gic synaptogenesis by EphB receptors. J Neurosci 26: $12152-12164$.

Kim S, Burette A, Chung HS, Kwon SK, Woo J, Lee HW, Kim K, Kim H, Weinberg RJ, Kim E. 2006. NGL family PSD-95-interacting adhesion molecules regulate excitatory synapse formation. Nat Neurosci 9: 1294-1301.

Knott GW, Quairiaux C, Genoud C, Welker E. 2002. Formation of dendritic spines with GABAergic synapses induced by whisker stimulation in adult mice. Neuron 34: 265-273.

Ko J, Kim S, Chung HS, Kim K, Han K, Kim H, Jun H, Kaang BK, Kim E. 2006. SALM synaptic cell adhesion-like molecules regulate the differentiation of excitatory synapses. Neuron 50: 233-245.

Ko J, Zhang C, Araç D, Boucard AA, Brunger AT, Südhof TC. 2009a. Neuroligin-1 performs neurexin-dependent and neurexin-independent functions in synapse validation. EMBO J 28: 3244-3255.

Ko J, Fuccillo MV, Malenka RC, Südhof TC. 2009b. LRRTM2 functions as a neurexin ligand in promoting excitatory synapse formation. Neuron 64: 791-798.

Ko J, Soler-Llavina GJ, Fuccillo MV, Malenka RC, Südhof TC. 2011. Neuroligins/LRRTMs prevent activity- and $\mathrm{Ca}^{2+} /$ calmodulin-dependent synapse elimination in cultured neurons. J Cell Biol 194: 323-334.

Koch SM, Ullian EM. 2010. Neuronal pentraxins mediate silent synapse conversion in the developing visual system. $J$ Neurosci 30: 5404-5414.

Lai KO, Ip NY. 2009. Synapse development and plasticity: Roles of ephrin/Eph receptor signaling. Curr Opin Neurobiol 19: 275-283.

Laurén J, Airaksinen MS, Saarma M, Timmusk T. 2003. A novel gene family encoding leucine-rich repeat transmembrane proteins differentially expressed in the nervous system. Genomics 81: 411-421.

Li J, Ashley J, Budnik V, Bhat MA. 2007. Crucial role of Drosophila neurexin in proper active zone apposition to postsynaptic densities, synaptic growth, and synaptic transmission. Neuron 55: 741-755.

Lim BK, Matsuda N, Poo MM. 2008. Ephrin-B reverse signaling promotes structural and functional synaptic maturation in vivo. Nat Neurosci 11: 160-169.

Lin JC, Ho WH, Gurney A, Rosenthal A. 2003. The netrinG1 ligand NGL-1 promotes the outgrowth of thalamocortical axons. Nat Neurosci 6: 1270-1276.

Linhoff MW, Lauren J, Cassidy RM, Dobie FA, Takahashi H, Nygaard HB, Airaksinen MS, Strittmatter SM, Craig AM. 2009. An unbiased expression screen for synaptogenic proteins identifies the LRRTM protein family as synaptic organizers. Neuron 61: 734-749.

Lucic V, Yang T, Schweikert G, Forster F, Baumeister W. 2005. Morphological characterization of molecular complexes present in the synaptic cleft. Structure 13: 423-434.

Luikart BW, Nef S, Virmani T, Lush ME, Liu Y, Kavalali ET, Parada LF. 2005. TrkB has a cell-autonomous role in the establishment of hippocampal Schaffer collateral synapses. J Neurosci 25: 3774-3786.

Lyckman AW, Horng S, Leamey CA, Tropea D, Watakabe A, Van Wart A, McCurry C, Yamamori T, Sur M. 2008. Gene expression patterns in visual cortex during the critical 
M. Missler et al.

period: Synaptic stabilization and reversal by visual deprivation. Proc Natl Acad Sci 105: 9409-9414.

Matsuda K, Yuzaki M. 2011. Cbln family proteins promote synapse formation by regulating distinct neurexin signaling pathways in various brain regions. Eur J Neurosci 33: $1447-1461$.

Mendez P, De Roo M, Poglia L, Klauser P, Muller D. 2010. $\mathrm{N}$-cadherin mediates plasticity-induced long-term spine stabilization. J Cell Biol 189: 589-600.

Miller MT, Mileni M, Comoletti D, Stevens RC, Harel M, Taylor P. 2011. The crystal structure of the $\alpha$-neurexin- 1 extracellular region reveals a hinge point for mediating synaptic adhesion and function. Structure 19: 767-778.

Missler M, Südhof TC. 1998. Neurexophilins form a conserved family of neuropeptide-like glycoproteins. $\mathrm{J} \mathrm{Neu-}$ rosci 18: 3630-3638.

Missler M, Zhang WQ, Rohlmann A, Kattenstroth G, Hammer RE, Gottmann K, Südhof TC. 2003. $\alpha$-neurexin couple $\mathrm{Ca}^{2+}$ channels to synaptic vesicle exocytosis. $\mathrm{Na}$ ture 423: 939-948.

Mizoguchi A, Nakanishi H, Kimura K, Matsubara K, OzakiKuroda K, Katata T, Honda T, Kiyohara Y, Heo K, Higashi M, et al. 2002. Nectin: An adhesion molecule involved in formation of synapses. J Cell Biol 156: 555-565.

Muller D, Wang C, Skibo G, Toni N, Cremer H, Calaora V, Rougon G, Kiss JZ. 1996. PSA-NCAM is required for activity-induced synaptic plasticity. Neuron 17: 413-422.

Murai KK, Nguyen LN, Irie F, Yamaguchi Y, Pasquale EB. 2003. Control of hippocampal dendritic spine morphology through ephrin-A3/EphA4 signaling. Nat Neurosci 6: $153-160$.

Nakashiba T, Nishimura S, Ikeda T, Itohara S. 2002. Complementary expression and neurite outgrowth activity of netrin-G subfamily members. Mech Dev 111: 47-60.

Nam CI, Chen L. 2005. Postsynaptic assembly induced by neurexin-neuroligin interaction and neurotransmitter. Proc Natl Acad Sci 102: 6137-6142.

Nam J, Mah W, Kim E. 2011. The SALM/Lrfn family of leucine-rich repeat-containing cell adhesion molecules. Semin Cell Dev Biol 22: 492-498.

Nozumi M, Togano T, Takahashi-Niki K, Lu J, Honda A, Taoka M, Shinkawa T, Koga H, Takeuchi K, Isobe T, Igarashi M. 2009. Identification of functional marker proteins in the mammalian growth cone. Proc Natl Acad Sci 106: 17211-17216.

O'Brien R, Xu D, Mi R, Tang X, Hopf C, Worley P. 2002. Synaptically targeted narp plays an essential role in the aggregation of AMPA receptors at excitatory synapses in cultured spinal neurons. J Neurosci 22: 4487-4498.

Palade GE, Palay SL. 1954. Electron microscope observations of interneuronal and neuromuscular synapses. Anat Record 118: 335-336.

Phillips GR, Tanaka H, Frank M, Elste A, Fidler L, Benson DL, Colman DR. 2003. $\gamma$-protocadherins are targeted to subsets of synapses and intracellular organelles in neurons. J Neurosci 23: 5096-5104.

Piechotta K, Dudanova I, Missler M. 2006. The resilient synapse: Insights from genetic interference of synaptic cell adhesion molecules. Cell Tissue Res 326: 617-642.
Pokutta S, Weis WI. 2007. Structure and mechanism of cadherins and catenins in cell-cell contacts. Annu Rev Cell Dev Biol 23: 237-261.

Polo-Parada L, Bose CM, Plattner F, Landmesser LT. 2004. Distinct roles of different neural cell adhesion molecule (NCAM) isoforms in synaptic maturation revealed by analysis of NCAM $180 \mathrm{kDa}$ isoform-deficient mice. $J$ Neurosci 24: 1852-1864.

Poulopoulos A, Aramuni G, Meyer G, Soykan T, Hoon M, Papadopoulos T, Zhang M, Paarmann I, Fuchs C, Harvey K, et al. 2009. Neuroligin 2 drives postsynaptic assembly at perisomatic inhibitory synapses through gephyrin and collybistin. Neuron 63: 628-642.

Price SR, De Marco Garcia NV, Ranscht B, Jessell TM. 2002. Regulation of motor neuron pool sorting by differential expression of type II cadherins. Cell 109: $205-$ 216.

Rees RP, Bunge MB, Bunge RP. 1976. Morphological changes in the neuritic growth cone and target neuron during synaptic junction development in culture. J Cell Biol 68: 240-263.

Reichardt LF. 2006. Neurotrophin-regulated signalling pathways. Philos Trans R Soc Lond B Biol Sci 361: 1545 1564.

Reissner C, Klose M, Fairless R, Missler M. 2008. Mutational analysis of the neurexin/neuroligin complex reveals essential and regulatory components. Proc Natl Acad Sci 105: 15124-15129.

Rex CS, Lin CY, Kramar EA, Chen LY, Gall CM, Lynch G. 2007. Brain-derived neurotrophic factor promotes longterm potentiation-related cytoskeletal changes in adult hippocampus. J Neurosci 27: 3017-3029.

Rico B, Xu BJ, Reichardt LF. 2002. TrkB receptor signaling is required for establishment of GABAergic synapses in the cerebellum. Nat Neurosci 5: 225-233.

Robbins EM, Krupp AJ, Perez de Arce K, Ghosh AK, Fogel AI, Boucard A, Südhof TC, Stein V, Biederer T. 2010. SynCAM 1 adhesion dynamically regulates synapse number and impacts plasticity and learning. Neuron 68: 894-906.

Rudenko G, Hohenester E, Muller YA. 2001. LG/LNS domains: Multiple functions—one business end? Trends Biochem Sci 26: 363-368.

Scheiffele P, Fan J, Choih J, Fetter R, Serafini T. 2000. Neuroligin expressed in nonneuronal cells triggers presynaptic development in contacting axons. Cell 101: 657-669.

Schikorski T, Stevens CF. 1997. Quantitative ultrastructural analysis of hippocampal excitatory synapses. J Neurosci 17: 5858-5867.

Seabold GK, Wang PY, Chang K, Wang CY, Wang YX, Petralia RS, Wenthold RJ. 2008. The SALM family of adhesionlike molecules forms heteromeric and homomeric complexes. J Biol Chem 283: 8395-8405.

Segura I, Essmann CL, Weinges S, Acker-Palmer A. 2007. Grb4 and GIT1 transduce ephrinB reverse signals modulating spine morphogenesis and synapse formation. Nat Neurosci 10: 301-310.

Shen K, Fetter RD, Bargmann CI. 2004. Synaptic specificity is generated by the synaptic guidepost protein SYG-2 and its receptor, SYG-1. Cell 116: 869-881. 
Shipman SL, Schnell E, Hirai T, Chen BS, Roche KW, Nicoll RA. 2011. Functional dependence of neuroligin on a new non-PDZ intracellular domain. Nat Neurosci 14: 718 726.

Siddiqui TJ, Pancaroglu R, Kang Y, Rooyakkers A, Craig AM. 2010. LRRTMs and neuroligins bind neurexins with a differential code to cooperate in glutamate synapse development. J Neurosci 30: 7495-7506.

Soler-Llavina GJ, Fuccillo MV, Ko J, Südhof TC, Malenka RC. 2011. The neurexin ligands, neuroligins and LRRTMs, perform convergent and divergent synaptic functions in vivo. Proc Natl Acad Sci 108: 16502-16509.

Song JY, Ichtchenko K, Südhof TC, Brose N. 1999. Neuroligin 1 is a postsynaptic cell adhesion molecule of excitatory synapses. Proc Natl Acad Sci 96: 1100-1105.

Stagi M, Fogel AI, Biederer T. 2010. SynCAM 1 participates in axo-dendritic contact assembly and shapes neuronal growth cones. Proc Natl Acad Sci 107: 7568-7573.

Südhof TC. 2008. Neuroligins and neurexins link synaptic function to cognitive disease. Nature 455: 903-911.

Sugita S, Saito F, Tang J, Satz J, Campbell K, Südhof TC. 2001. A stoichiometric complex of neurexins and dystroglycan in brain. J Cell Biol 154: 435-445.

Sun M, Xing G, Yuan L, Gan G, Knight D, With SI, He C, Han J, Zeng X, Fang M, et al. 2011. Neuroligin 2 is required for synapse development and function at the Drosophila neuromuscular junction. J Neurosci 31: 687-699.

Sytnyk V, Leshchyns'ka I, Nikonenko AG, Schachner M. 2006. NCAM promotes assembly and activity-dependent remodeling of the postsynaptic signaling complex. $\mathrm{J} \mathrm{Cell}$ Biol 174: 1071-1085.

Tabuchi K, Südhof TC. 2002. Structure and evolution of neurexin genes: Insight into the mechanism of alternative splicing. Genomics 79: 849-859.

Tabuchi K, Blundell J, Etherton MR, Hammer RE, Liu X, Powell CM, Südhof TC. 2007. A neuroligin-3 mutation implicated in autism increases inhibitory synaptic transmission in mice. Science 318: 71-76.

Takahashi H, Arstikaitis P, Prasad T, Bartlett TE, Wang YT, Murphy TH, Craig AM. 2011. Postsynaptic TrkC and presynaptic PTP $\sigma$ function as a bidirectional excitatory synaptic organizing complex. Neuron 69: 287-303.

Thomas LA, Akins MR, Biederer T. 2008. Expression and adhesion profiles of SynCAM molecules indicate distinct neuronal functions. J Comp Neurol 510: 47-67.

Togashi H, Abe K, Mizoguchi A, Takaoka K, Chisaka O, Takeichi M. 2002. Cadherin regulates dendritic spine morphogenesis. Neuron 35: 77-89.

Togashi H, Miyoshi J, Honda T, Sakisaka T, Takai Y, Takeichi M. 2006. Interneurite affinity is regulated by heterophilic nectin interactions in concert with the cadherin machinery. J Cell Biol 174: 141-151.

Toni N, Buchs PA, Nikonenko I, Bron CR, Muller D. 1999. LTP promotes formation of multiple spine synapses between a single axon terminal and a dendrite. Nature 402: $421-425$.

Uchida N, Honjo Y, Johnson KR, Wheelock MJ, Takeichi M. 1996. The catenin/cadherin adhesion system is localized in synaptic junctions bordering transmitter release zones. J Cell Biol 135: 767-779.
Uemura T, Lee SJ, Yasumura M, Takeuchi T, Yoshida T, Ra M, Taguchi R, Sakimura K Mishina M. 2010. Trans-synaptic interaction of GluR $\Delta 2$ and neurexin through Cbln 1 mediates synapse formation in the cerebellum. Cell 141: $1068-1079$.

Ullrich B, Ushkaryov YA, Südhof TC. 1995. Cartography of neurexins: More than 1000 isoforms generated by alternative splicing and expressed in distinct subsets of neurons. Neuron 14: 497-507.

Ushkaryov YA, Südhof TC. 1993. Neurexin III $\alpha$ : Extensive alternative splicing generates membrane-bound and soluble forms. Proc Natl Acad Sci 90: 6410-6414.

Ushkaryov YA, Petrenko AG, Geppert M, Südhof TC. 1992. Neurexins: Synaptic cell surface proteins related to the $\alpha$ - latrotoxin receptor and laminin. Science 257: $50-56$.

Ushkaryov YA, Hata Y, Ichtchenko K, Moomaw C, Afendis S, Slaughter CA, SüdhofTC. 1994. Conserved domain structure of $\beta$-neurexins. Unusual cleaved signal sequences in receptor-like neuronal cell-surface proteins. J Biol Chem 269: 11987-11992.

Varoqueaux F, Jamain S, Brose N. 2004. Neuroligin 2 is exclusively localized to inhibitory synapses. Eur J Cell Biol 83: $449-456$.

Varoqueaux F, Aramuni G, Rawson RL, Mohrmann R, Missler M, Gottmann K, Zhang W, Südhof TC, Brose N. 2006. Neuroligins determine synapse maturation and function. Neuron 51: 741-754.

Wang XZ, Weiner JA, Levi S, Craig AM, Bradley A, Sanes JR. 2002. $\gamma$ protocadherins are required for survival of spinal interneurons. Neuron 36: 843-854.

Wang CY, Chang K, Petralia RS, Wang YX, Seabold GK, Wenthold RJ. 2006. A novel family of adhesion-like molecules that interacts with the NMDA receptor. J Neurosci 26: $2174-2183$.

Weiner JA, Wang X, Tapia JC, Sanes JR. 2005. $\gamma$ protocadherins are required for synaptic development in the spinal cord. Proc Natl Acad Sci 102: 8-14.

Woo RS, Li XM, Tao Y, Carpenter-Hyland E, Huang YZ, Weber J, Neiswender H, Dong XP, Wu J, Gassmann M, et al. 2007. Neuregulin-1 enhances depolarization-induced GABA release. Neuron 54: 599-610.

Woo J, Kwon SK, Kim E. 2009. The NGL family of leucinerich repeat-containing synaptic adhesion molecules. Mol Cell Neurosci 42: 1-10.

Yamagata M, Sanes JR. 2008. Dscam and Sidekick proteins direct lamina-specific synaptic connections in vertebrate retina. Nature 451: 465-469.

Yamagata M, Weiner JA, Sanes JR. 2002. Sidekicks: Synaptic adhesion molecules that promote lamina-specific connectivity in the retina. Cell 110: 649-660.

Zelano J, Berg A, Thams S, Hailer NP, Cullheim S. 2009. SynCAM 1 expression correlates with restoration of central synapses on spinal motoneurons after two different models of peripheral nerve injury. J Comp Neurol 517: 670-682.

Zhang W, Rohlmann A, Sargsyan V, Aramuni G, Hammer RE, Südhof TC, Missler M. 2005a. Extracellular domains of $\alpha$-neurexins participate in regulating synaptic transmission by selectively affecting $\mathrm{N}$ - and $\mathrm{P} / \mathrm{Q}$-type $\mathrm{Ca}^{2+}$ channels. J Neurosci 25: 4330-4342. 
M. Missler et al.

Zhang Q, Wang J, Fan S, Wang L, Cao L, Tang K, Peng C, Li Z, Li W, Gan K, et al. 2005b. Expression and functional characterization of LRRC4, a novel brain-specific member of the LRR superfamily. FEBS Lett 579: $3674-$ 3682.

Zhang Q, Rajan I, Savelieva KV, Wang CY, Vogel P, Kelly M, Xu N, Hasson B, Jarman W, Lanthorn TH. 2008. Netrin-G2 and netrin-G2 ligand are both required for normal auditory responsiveness. Genes Brain Behav 7: 385-392.

Zhang C, Atasoy D, Araç D, Yang X, Fucillo MV, Robison AJ, Ko J, Brunger AT, Südhof TC. 2010. Neurexins physically and functionally interact with GABA(A) receptors. Neuron 66: 403-416.
Zhen M, Jin Y. 1999. The liprin protein SYD-2 regulates the differentiation of presynaptic termini in C. elegans. Nature 401: 371-375.

Zoghbi HY. 2003. Postnatal neurodevelopmental disorders: Meeting at the synapse? Science 302: 826-830.

Zuber B, Nikonenko I, Klauser P, Muller D, Dubochet J. 2005. The mammalian central nervous synaptic cleft contains a high density of periodically organized complexes. Proc Natl Acad Sci 102: 19192-19197.

Zuko A, Bouyain S, van der Zwaag B, Burbach JP. 2011. Contactins: Structural aspects in relation to developmental functions in brain disease. Adv Protein Chem Struct Biol 84: $143-180$. 


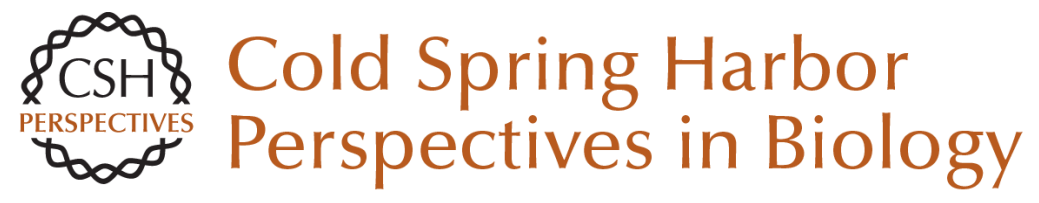

\section{Synaptic Cell Adhesion}

Markus Missler, Thomas C. Südhof and Thomas Biederer

Cold Spring Harb Perspect Biol 2012; doi: 10.1101/cshperspect.a005694 originally published online January 25, 2012

\section{Subject Collection The Synapse}

Studying Signal Transduction in Single Dendritic Spines Ryohei Yasuda

Synaptic Vesicle Pools and Dynamics AbdulRasheed A. Alabi and Richard W. Tsien

Synapses and Memory Storage Mark Mayford, Steven A. Siegelbaum and Eric $R$. Kandel

Synapses and Alzheimer's Disease Morgan Sheng, Bernardo L. Sabatini and Thomas C. Südhof

Synaptic Cell Adhesion Markus Missler, Thomas C. Südhof and Thomas Biederer

Synaptic Dysfunction in Neurodevelopmental Disorders Associated with Autism and Intellectual Disabilities

Huda Y. Zoghbi and Mark F. Bear

The Postsynaptic Organization of Synapses Morgan Sheng and Eunjoon Kim

Presynaptic LTP and LTD of Excitatory and Inhibitory Synapses

Pablo E. Castillo
Synaptic Vesicle Endocytosis

Yasunori Saheki and Pietro De Camilli

Short-Term Presynaptic Plasticity Wade G. Regehr

NMDA Receptor-Dependent Long-Term

Potentiation and Long-Term Depression

(LTP/LTD) Christian Lüscher and Robert C. Malenka

Ultrastructure of Synapses in the Mammalian

Brain Kristen M. Harris and Richard J. Weinberg

Calcium Signaling in Dendritic Spines Michael J. Higley and Bernardo L. Sabatini

Synaptic Neurotransmitter-Gated Receptors Trevor G. Smart and Pierre Paoletti

Synaptic Vesicle Exocytosis

Thomas C. Südhof and Josep Rizo

Vesicular and Plasma Membrane Transporters for Neurotransmitters

Randy D. Blakely and Robert H. Edwards

For additional articles in this collection, see http://cshperspectives.cshlp.org/cgi/collection/

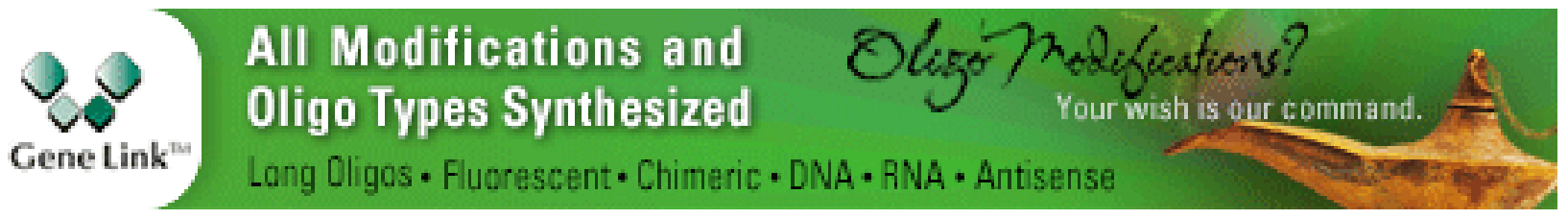

